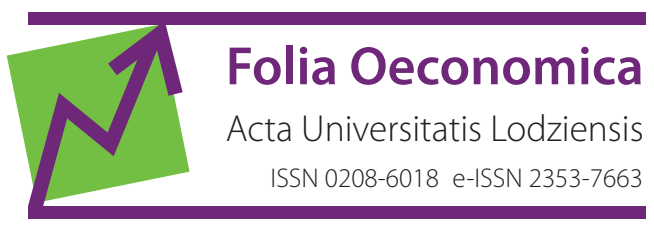

www.czasopisma.uni.lodz.pl/foe/

5(331) 2017

DOI: http://dx.doi.org/10.18778/0208-6018.331.06

\author{
Anna Janiszewska \\ Uniwersytet Łódzki, Wydział Nauk Geograficznych, Katedra Geografii Regionalnej i Społecznej, \\ anna.janiszewska@geo.uni.lodz.pl
}

\title{
Zróżnicowanie przestrzenne starzenia się ludności na świecie
}

Streszczenie: Starzenie się ludności jest procesem, który obecnie ma zasięg globalny i dotyczy niemal wszystkich regionów świata, choć przebiega bardzo nierównomiernie w skali poszczególnych krajów. Niewątpliwie obserwowane współcześnie przemiany zachowań demograficznych przyczyniają się do pogłębiania rozmiarów tego zjawiska, niemniej jednak sam proces rozpoczął się dużo wcześniej. W opracowaniu poddano analizie dane statystyczne i potwierdzono, że najwyższy poziom starości demograficznej występuje już od pół wieku na kontynencie europejskim. Należy jednak stwierdzić, że dynamika starzenia się ludności w Europie począwszy od lat dziewięćdziesiątych jest niższa niż w Ameryce Środkowej i Południowej czy w Azji, co oznacza rozprzestrzenianie się tego zjawiska na inne kontynenty. Głównym celem opracowania jest pokazanie zróżnicowania przestrzennego starzenia się ludności na świecie według kontynentów i krajów.

Słowa kluczowe: starzenie się społeczeństw, ludzie starzy, zróżnicowanie przestrzenne, świat, kontynenty

JEL: J11, J13, J14, R23 


\section{Wprowadzenie}

E. Rosset (1982), wybitny polski demograf pisał, że najważniejszymi problemami ludnościowymi XX w. - zarówno w skali europejskiej, jak i ogólnoświatowej - były eksplozja demograficzna, wydłużanie się trwania życia oraz proces starzenia się ludności. I. Stuart-Hamilton (2006) podkreśla, że starzenie się ludności nie jest zjawiskiem nowym, ale dopiero w XX w. stało się powszechne.

Jeszcze w połowie ubiegłego wieku starzenie się ludności nie było traktowane jako ważny problem społeczny przez społeczność międzynarodową (Mikołajczyk, 2012). Chociaż odbywały się spotkania z inicjatywy ONZ mające na celu ustalenie strategii działań dotyczących rozwiązywania najważniejszych problemów osób starszych (Argentyna 1948 r., Malta 1969 r.), to nie spowodowały one podjęcia dalszych działań w kierunku rozwiązywania kwestii tych osób. Pierwsze Światowe Zgromadzenie na Temat Osób Starszych zwołane przez ONZ odbyło się w Wiedniu w 1982 r. Efektem obrad wiedeńskich był raport określający międzynarodowy plan działania dotyczący problemów starszego pokolenia oraz Deklaracja Zasad Narodów Zjednoczonych, zwana także Deklaracją Wiedeńską, w odniesieniu do ludzi starszych (Golinowska, Mazurkiewicz, 1999). Drugie Światowe Zgromadzenie na Temat Starzenia się Społeczeństw odbyło się w 2002 r. w Madrycie. Jego efektem było opracowanie Międzynarodowej Strategii Działania w Kwestii Starzenia Się Społeczeństw, uwzględniające następujące kwestie: zapewnienie bezpiecznej starości poprzez eliminację ubóstwa, stworzenie osobom starszym możliwości uczestnictwa w życiu społecznym i politycznym (Ministerstwo Rodziny, Pracy i Polityki Społecznej, 2002).

Problematyka związana ze starzeniem się ludności na świecie jest obecna współcześnie, zarówno w wielu opracowaniach naukowych, jak i dokumentach organizacji oraz instytucji międzynarodowych (ONZ, WHO, UE). Proces starzenia się mieszkańców naszego globu jest bardzo zróżnicowany przestrzennie - nie tylko ze względu na jego rozmiary, ale i dynamikę tych zmian. Niewątpliwie zróżnicowanie to jest wynikiem przemian ludnościowych związanych z pierwszym i drugim przejściem demograficznym, których kolebką był kontynent europejski.

Przemiany demograficzne pierwszego i drugiego przejścia demograficznego (przede wszystkim obniżenie rodności i śmiertelności) zapoczątkowały „nowoczesny" proces starzenia (Rosset, 1982), albo jak mówią przedstawiciele nauk społecznych powstawania „siwiejącej populacji” (Giddens, 2005) albo „siwiejącego pokolenia" (Stuart-Hamilton, 2006). W aspekcie demograficznym starzenie się ludności jest procesem dynamicznie zwiększającego się udziału seniorów (w wieku 65 lat i więcej) w ogólnej liczbie ludności. Szczególnie istotne jest to, że dalszym zmianom ulegają proporcje liczby ludności w wieku produkcyjnym i poprodukcyjnym. Oczywiste jest, że struktura wiekowa społeczeństwa wywiera wpływ na rozwój gospodarczy kraju. Dzieje się tak choćby dlatego, że ludzi w różnym wieku charakteryzują odmienne potrzeby. Wykazują się oni zróżnico- 
wanymi zachowaniami ekonomicznymi (Bloom, Canning, Sevilla, 2001). Istotne jest także to, że zmiany w strukturze demograficznej, poza zwiększeniem skali obciążeń budżetowych oraz trudności w systemach emerytalnych i opiece zdrowotnej, mogą niekorzystnie oddziaływać na dynamikę gospodarczą i konkurencyjność (Grzędzińska, 2005).

W kontekście bardzo wyraźnych zmian struktury wieku ludności na świecie, w tym zwiększania się populacji ludzi starych, istotne z poznawczego punktu widzenia jest określenie dywersyfikacji przestrzennej zjawiska starzenia się ludności. Głównym celem opracowania jest zatem pokazanie zróżnicowania przestrzennego starzenia się ludności na świecie według kontynentów i krajów. Rozpatrując starzenie się ludności świata jako proces, uwzględniono w opracowaniu jego dynamikę od lat pięćdziesiątych ubiegłego wieku. Analiza przeprowadzona dla krajów objęła lata 1990-2014.

\section{Starość w perspektywie globalnej i kontynentalnej}

Demograficzne starzenie się dotyczy populacji całego świata, jest więc procesem globalnym (global ageing). Stopień jego zaawansowania nie jest jednak wszędzie jednakowy. W regionach wysoko rozwiniętych (Europa, Ameryka Północna bez części łacińskiej, Australia z Nową Zelandią, Japonia) stopa starości kształtuje się na zdecydowanie wyższym poziomie (obecnie prawie trzy razy) niż w regionach słabiej rozwiniętych (Afryka, Azja bez Japonii, Ameryka Łacińska, Karaiby). Można zatem stwierdzić, że stopa starości uzależniona jest od poziomu rozwoju społeczno-gospodarczego. Wyższy poziom rozwoju to wyższy poziom życia i większa szansa dożycia okresu starości, co zwiększa liczbę ludzi starych (Jurek, 2008).

W połowie XX w. największy odsetek ludzi starych występował na kontynentach północnoamerykańskim $(8,2 \%)$ i europejskim (8\%). Jeszcze do połowy lat sześćdziesiątych kontynent północnoamerykański był bardziej zaawansowany w procesie starzenia się niż Europa, choć różnice pomiędzy udziałami osób w wieku 65 lat i więcej na obu kontynentach były niewielkie (rys. 1). Od tego czasu Europa stała się regionem o największym poziomie starości demograficznej.

Od początku lat dziewięćdziesiątych dynamika przyrostu odsetka ludzi starych uległa zwiększeniu. Odsetek ludności starej na świecie, tj. w wieku 65 lat i więcej wyniósł $6,2 \%$ (5,2\% mężczyzn i 7,2\% kobiet). Najbardziej zaawansowanym kontynentem pod względem starzenia się ludności była Europa $(13,5 \%)$. W latach 1990-2014 odsetek ludności starej wzrósł na świecie o blisko 2 punkty procentowe, a na kontynencie europejskim o prawie 4 (rys. 2). Zgodnie z propozycją progu starości określoną przez ONZ (7\%), populacja świata przekroczyła tę granicę na początku XXI w. (Kurkiewicz, 1992). 


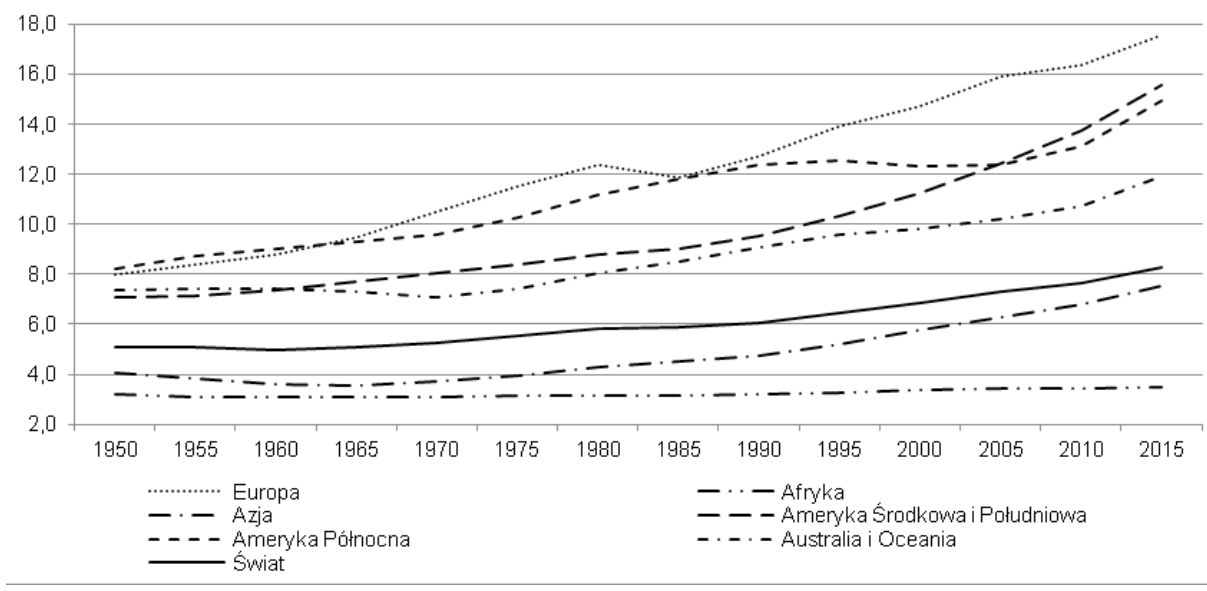

Rysunek 1. Odsetek ludzi w wieku 65 lat i więcej w 1990 i 2014 r.

Źródło: opracowanie własne na podstawie bazy danych UNSD

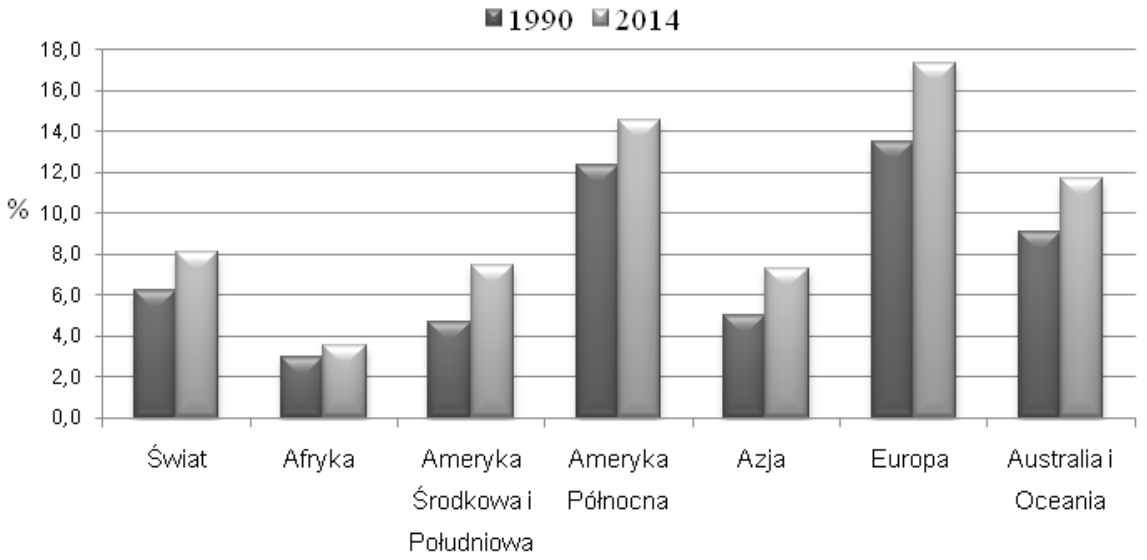

Rysunek 2. Odsetek ludzi w wieku 65 lat i więcej w 1990 i 2014 r.

Źródło: opracowanie własne na podstawie bazy danych UNSD.

Pod względem zaawansowania procesu starzenia się ludności Europa jest kontynentem o największym poziomie starzenia się ludności. Indeks starości demograficznej w 2014 r. przekroczył wartość 100, co oznacza, że udział ludności starej przekroczył udział dzieci do 14. roku życia (tab. 1). Miarą zaś dynamiki procesu starzenia się ludności jest m.in. współczynnik starzenia się ludności. Im wartość tego wskaźnika jest wyższa, tym starzenie się społeczeństwa jest bardziej dynamiczne, zaś ujemna wartość świadczy o odmładzaniu się populacji (Długosz, 1998; Kurek, 2008). W rozpatrywanym okresie, tj. w latach 1990-2014 kontynent europejski wykazał się dużą dynamiką starzenia się ludności. Podkreślić jednak 
należy, że w Ameryce Środkowej i Południowej oraz Azji tempo starzenia się było większe niż w Europie (tab. 1). W regionie Azji, Ameryki Południowej i Środkowej zmiany demograficzne polegające na starzeniu się ludności rozpoczęły się później niż w krajach europejskich, jednak obecnie ich przebieg jest znacznie szybszy.

Tabela 1. Zmiany wartości indeksu starości demograficznej $\left(I_{S D}\right)$ oraz wskaźnika starzenia się demograficznego $\left(W_{S D}\right)$ według kontynentów w latach 1990-2014

\begin{tabular}{|l|c|c|c|}
\hline \multirow{2}{*}{ Wyróżnienie } & \multicolumn{2}{|c|}{$\begin{array}{c}\text { Indeks starości } \\
\text { demograficznej }\left(\boldsymbol{I}_{\boldsymbol{S D}}\right)\end{array}$} & $\begin{array}{c}\text { Współczynnik starzenia } \\
\text { się demograficznego }\left(\boldsymbol{W}_{\boldsymbol{S D}}\right)\end{array}$ \\
\cline { 2 - 3 } & $\mathbf{1 9 9 0}$ & $\mathbf{2 0 1 4}$ & $\mathbf{2 0 1 4}$ \\
\hline Świat & 19,2 & 30,9 & 8,0 \\
\hline Afryka & 6,6 & 8,5 & 4,4 \\
\hline Ameryka Środkowa i Południowa & 13,1 & 28,3 & 12,5 \\
\hline Ameryka Północna & 57,6 & 77,3 & 4,8 \\
\hline Azja & 15,2 & 29,6 & 10,6 \\
\hline Europa & 68,3 & 110,5 & 7,9 \\
\hline Australia i Oceania & 34,3 & 49,7 & 5,5 \\
\hline
\end{tabular}

Źródło: opracowanie własne na podstawie bazy danych UNSD

\section{Zróżnicowanie przestrzenne starzenia się ludności według państw}

\subsection{Zaawansowanie starzenia się ludności}

Poziom starzenia się ludności określony udziałem osób w wieku 65 lat i więcej jest bardzo zróżnicowany przestrzennie (rys. 3). Udział seniorów w poszczególnych krajach waha się od 1\% w Zjednoczonych Emiratach Arabskich do 25,8\% w Japonii. Najmniejszymi udziałami osób 65+ (do zaledwie 2,5\%) odznaczało się w roku 2014 - 11 państw (głównie afrykańskich i azjatyckich z Bliskiego Wschodu). Były to (obok ZEA): Afganistan, Angola, Bahrajn, Burkina Faso, Benin, Burundi, Czad, Gambia, Katar, Kuwejt. Następne 72 kraje (w przeważającej większości afrykańskie) charakteryzowały się udziałem od 2,6\% do 5\% osób starszych. Na drugim biegunie w rankingu pod względem największego odsetka osób w wieku 65 lat i więcej plasuje się, oprócz wspomnianej już Japonii, 5 krajów europejskich, gdzie co piąty mieszkaniec jest osobą starą. Krajami tymi są: Włochy (22\%), Niemcy (21,1\%), Grecja (20,9\%), Finlandia (19,8\%), Portugalia (20,4\%). W Polsce udział osób starszych wyniósł $15 \%$, tym samym nasz kraj znalazł się w grupie 35 krajów, w których wartości odsetka były od 14 do 20\%. 
W krajach o najniższym odsetku osób starszych bardzo duża jest populacja dzieci i młodzieży. W blisko 40 krajach świata udział osób w wieku 0-14 lat w 2014 r. przekroczył 40\%, a wartość maksymalną odnotował Niger - 50,4\%. Były to kraje o bardzo wysokiej dzietności. W grupie krajów młodych demograficznie (o niskim udziale osób starych) znalazły się też państwa, których struktura wieku ludności jest ściśle związana z podstawami ich rozwoju gospodarczego. Są to kraje, których gospodarki opierają się na wydobyciu i przetwórstwie ropy naftowej, a pracownicy zatrudnieni w tej gałęzi w dużej mierze są imigrantami. Dlatego, np. w Kuwejcie, Katarze, Omanie czy Arabii Saudyjskiej udział osób w wieku produkcyjnym jest bardzo wysoki (75-85\%), co wpływa na niższe wartości odsetków pozostałych grup wieku w tych krajach ${ }^{1}$.

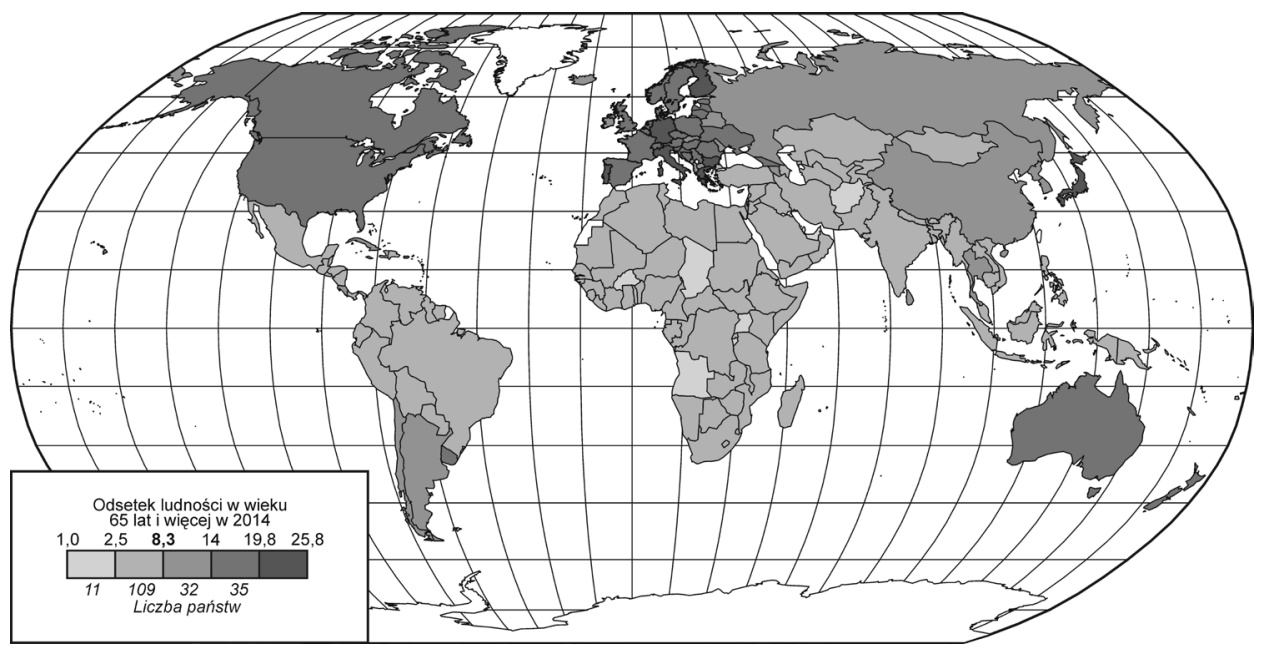

Rysunek 3. Odsetek ludności w wieku 65 lat i więcej w 2014 r.

Źródło: opracowanie własne na podstawie bazy danych World Bank

Starzenie się ludności na świecie postępuje od kilkudziesięciu lat, ale jeszcze w 1990 r. żaden kraj nie osiągnął indeksu starości demograficznej powyżej 100 (rys. 4). Znaczy to, że we wszystkich krajach na świecie występowała przewaga liczebna osób w wieku 0-14 lat nad ludźmi powyżej 65. roku życia. Najbliżej tej wartości były kraje europejskie (13 państw), które osiągnęły wartości od 70 do 99. Aż w 136 krajach indeks był niski lub bardzo niski (od 3,4 do 22,9). Po upływie ćwierćwiecza już w 30 krajach osoby starsze przeważały liczebnie nad grupą dzie-

${ }^{1}$ Innym skutkiem napływu siły roboczej do tych krajów jest wysoka maskulinizacja tych społeczeństw, np. w 2013 roku współczynnik maskulinizacji wyniósł w Katarze - 281, w ZEA - 216, w Omanie - 164, http://unstats.un.org/unsd/demographic/products/dyb/dyb2014.htm [dostęp: 5.08.2016]. 
ci i młodzieży, a wartość maksymalną odnotowano w Japonii $(198,7)$. Wśród tych krajów, z wyjątkiem wspomnianej Japonii i Hong Kongu, wszystkie były krajami europejskimi. Polska także należała do tej grupy z wartością $I_{S D}-109$ (rys. 5).

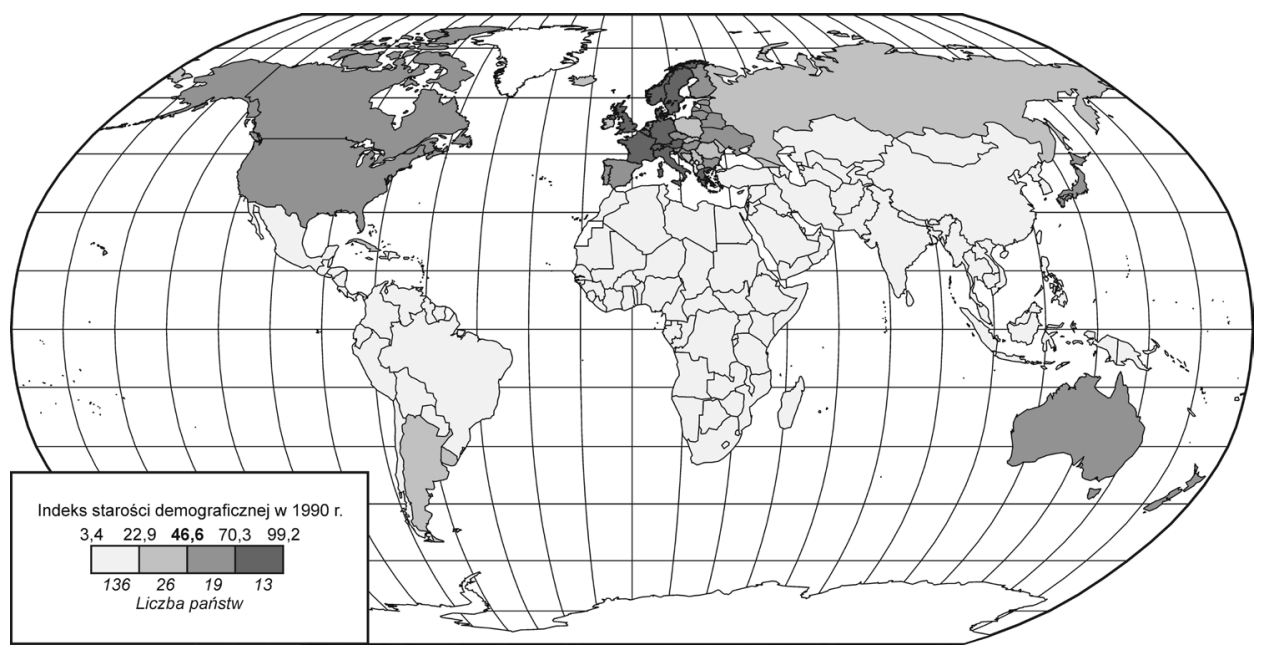

Rysunek 4. Indeks starości demograficznej w 1990 r.

Źródło: opracowanie własne na podstawie bazy danych World Bank

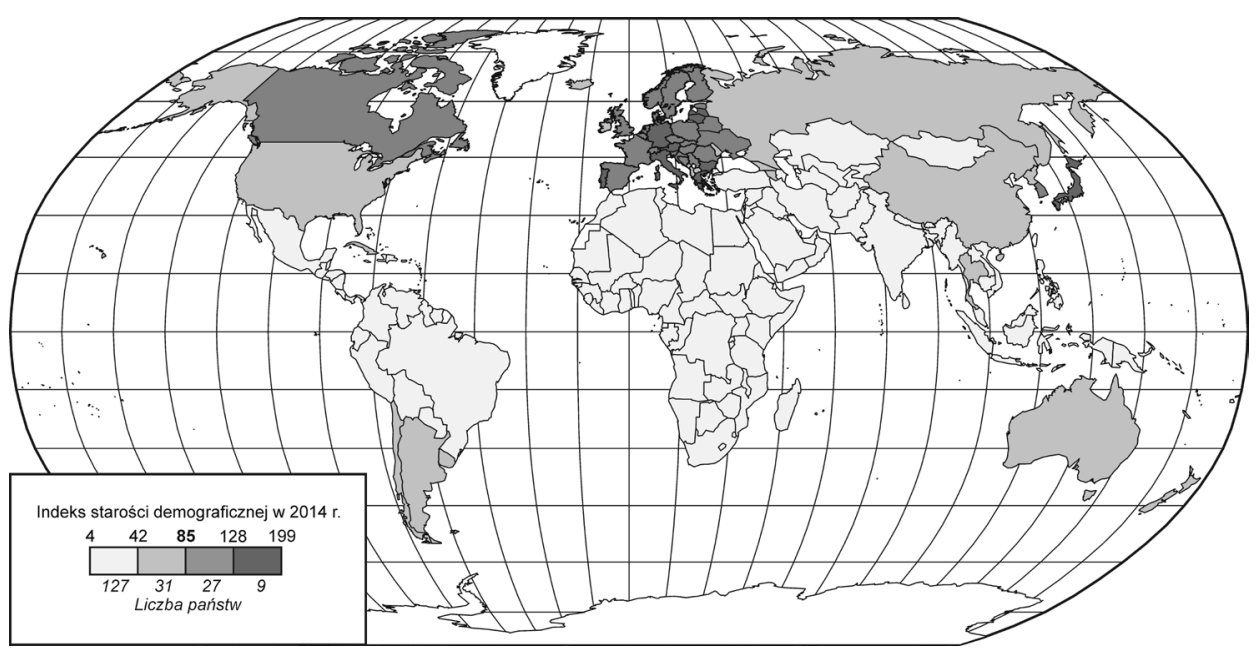

Rysunek 5. Indeks starości demograficznej w 2014 r.

Źródło: opracowanie własne na podstawie bazy danych World Bank 


\subsection{Dynamika starzenia się ludności}

Badanie dynamiki starzenia się na świecie wskazuje na postępujący proces zmian struktury wieku ludności. Generalnie średnia wartość wskaźnika starzenia się demograficznego $\left(W_{S D}\right)$ w latach 1990-2014 dla ogółu mieszkańców świata wyniosła 8. Tylko 9 krajów na świecie odnotowało odmłodzenie (ujemne wartości $W_{S D}$ ), były to: Angola, Czad, Demokratyczna Republika Konga, Gwinea Równikowa, Gambia, Mali, Niger, Somalia i Uganda (rys. 6). W Angoli odmłodzenie społeczeństwa nastąpiło poprzez zmniejszenie odsetka osób starych, a w Demokratycznej Republice Konga - poprzez zwiększenie odsetka młodych. W przypadku pozostałych 7 krajów był to wynik zarówno wzrostu udziału osób w wieku 0-14 lat, jak i spadku liczby osób w wieku 65 lat i więcej.

W przeważającej liczbie państw na świecie nastąpił proces starzenia, z największą wartością współczynnika w Omanie $(24,4)$, Iranie $(23,5)$ i na Malediwach $(21,9)$. W każdym z tych trzech krajów na wartość $W_{S D}$ zdecydowany wpływ miał spadek udziału najmłodszej części społeczeństwa, który stanowił adekwatnie 99\%, 93\% i 91\% wartości współczynnika starzenia demograficznego. Spadek odsetka dzieci i młodzieży w latach 1990-2014 nastąpił wskutek drastycznego obniżenia się dzietności w tych krajach. TFR (total fertility rate) zmniejszył się w Omanie z 7,2 do 2,8 dziecka przypadającego na kobietę, na Malediwach z 5,9 do 2,1, a w Iranie z 4,8 do 1,7. W tym ostatnim kraju wartość współczynnika dzietności nie gwarantuje nawet zastępowalności pokoleń. Zdaniem demografów największą niespodzianką jest szerzenie się zjawiska reprodukcji zawężonej w krajach arabskich i świecie muzułmańskim, wziąwszy pod uwagę ich powierzchnię. Zarówno Algieria, Tunezja, Liban, jak i Turcja to kraje, w których można mówić o reprodukcji zawężonej. Wyjątkowy przypadek stanowi wspomniany Iran, gdzie obecny wskaźnik dzietności $(1,7)$ wynosi mniej niż w Stanach Zjednoczonych $(2,1)$. W latach 1986-2000 wskaźnik dzietności w krajach arabskich spadł gwałtownie z poziomu powyżej 6 do 2 , co wynikało z przejmowania przez społeczeństwa tych krajów zachodniego stylu życia i podejmowania przez kobiety pracy zawodowej, co prowadzi także w wielu innych krajach do trwałego spadku wskaźnika dzietności. Do spadku wskaźnika dzietności przyczyniła się także polityka rządów wielu krajów, np. w Chinach polityka popierania tylko jednego dziecka w rodzinie czy też polityka ograniczenia przyrostu naturalnego w Indiach oraz w niektórych krajach Azji i Ameryki Łacińskiej (Gabryszak, 2005).

Grupą krajów, które osiągnęły także bardzo wysokie wartości $W_{S D}$ (od 15 do 20) było 25 państw położonych na różnych kontynentach - w Europie (w tym Polska), w Ameryce Południowej, w Azji, nawet w Afryce (Algieria, Tunezja). Należy odnotować, że proces starzenia w tych krajach następował zarówno wskutek spadku odsetka dzieci i młodzieży, jak i zwiększania się udziału osób starszych, tylko udział tych składników był zróżnicowany. Wśród tych krajów tylko na Ja- 
majce i Wyspach Dziewiczych Stanów Zjednoczonych postępujące starzenie nastąpiło w głównej mierze wskutek wzrostu udziału osób starszych, w pozostałych krajach to większy spadek odsetka osób w wieku 0-14 lat był dominującym czynnikiem starzenia się społeczeństw.

$\mathrm{Na}$ tle powyżej zarysowanych niekorzystnych tendencji demograficznych pewnym wyjątkiem jest sytuacja w Stanach Zjednoczonych. Proces starzenia się tego kraju jest o wiele bardziej umiarkowany niż w Europie czy Japonii, a także w wielu innych krajach. Tempo starzenia się ludności wyznaczone przez $W_{S D}(4,4)$ jest niskie, a indeks starości demograficznej $(75,5)$ wskazuje na korzystne relacje ilościowe między najmłodszą i najstarszą subpopulacją. Wynika to w dużym stopniu z wyższego w USA niż w Europie wskaźnika dzietności, który wynosi 2,1, a w Europie średnio tylko 1,4. Według prognoz, w Stanach Zjednoczonych jeszcze w 2025 r. będzie więcej młodych osób niż starych, dopiero na rok 2050 przewiduje się odwrócenie tych proporcji. Udział osób starszych będzie wynosił 19,1\%, a osób w wieku 0-14 lat tylko 17,5\%.

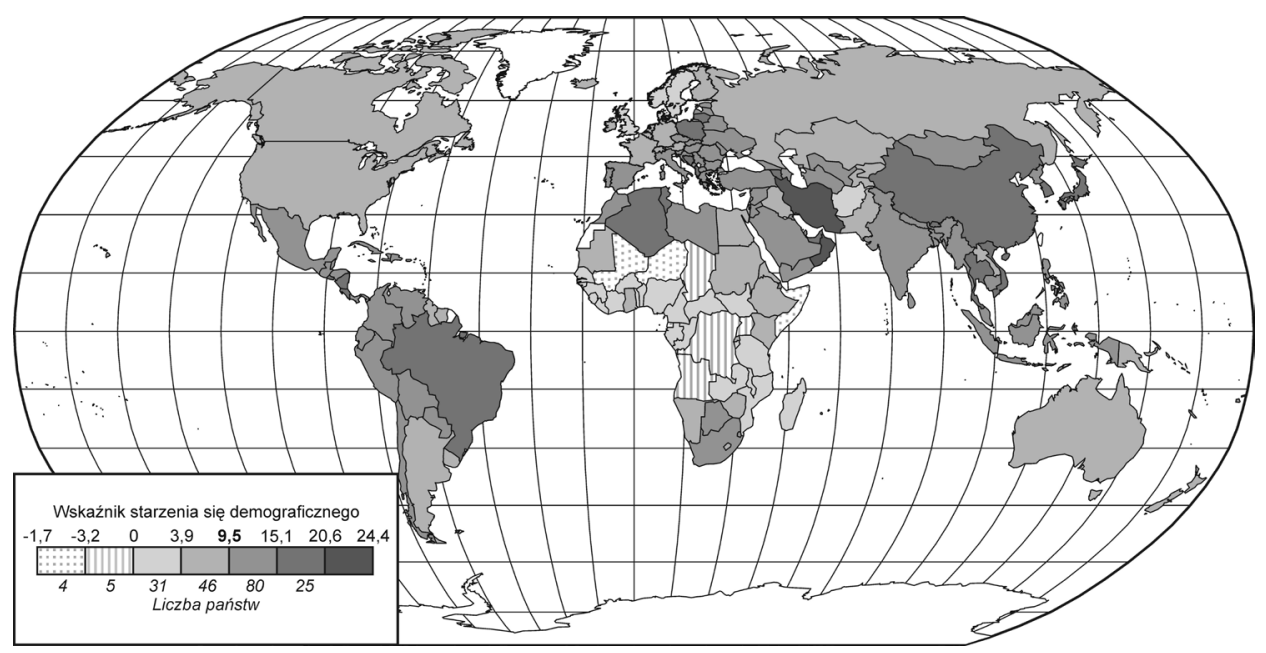

Rysunek 6. Wskaźnik starzenia się demograficznego w latach 1990-2014

Źródło: opracowanie własne na podstawie bazy danych World Bank

Prognoza demograficzna ONZ na rok 2050 zakłada, że proces starzenia będzie postępował nadal i nie będzie charakterystyczny już tylko dla krajów europejskich i Japonii (rys. 7). Do grupy państw ze starzejącym się społeczeństwem dołączą Kanada, Chiny, Chile, Korea Południowa, Tajlandia, Kuba, Hong Kong, Singapur. Zakłada się na przykład, że w Chinach w połowie XXI wieku zamieszkiwać będzie blisko pół miliarda seniorów, co stanowić będzie jedną czwartą światowej populacji ludzi starych, a w Singapurze liczba ludzi starych niemalże podwajać się ma z każdą dekadą (Jurek, 2008). 
Przewiduje się, że w 15 krajach (także w Polsce) w 2050 r. co trzeci mieszkaniec będzie miał 65 lat i więcej. Najwyższe wartości odsetka ludzi starych są przewidywane dla Japonii (36,4\%), Hiszpanii $(35,8 \%)$, Portugalii $(35,2 \%)$, Włoch $(35,1 \%)$ i Korei Południowej $(35,1 \%)$. Według prognozy bardzo duża dynamika starzenia się ludności (wzrost odsetka ludzi starych o 20\%) wystąpi także w krajach, które do tej pory nie były zaliczane do grupy państw ze starzejącym się społeczeństwem. Wśród tych krajów znajdą się: Singapur, Tajlandia, Korea Południowa, Hong Kong, Kuba i Brunei.

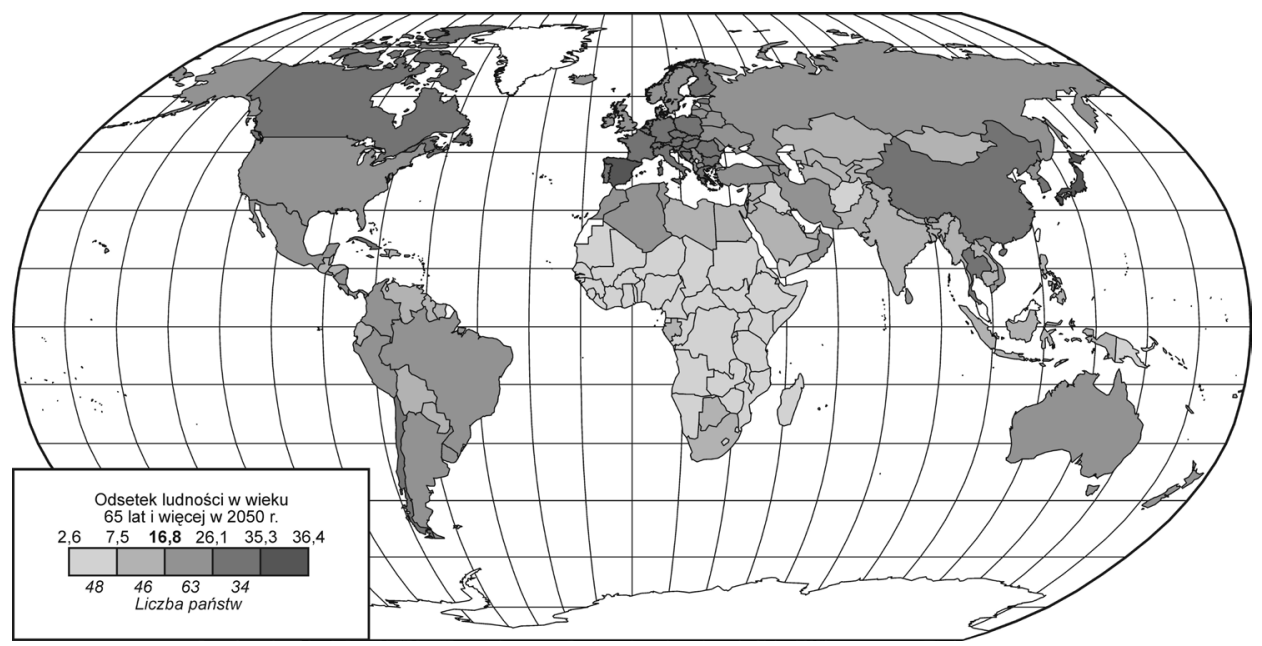

Rysunek 7. Odsetek ludności w wieku 65 lat i więcej w 2050 r.

Źródło: opracowanie własne na podstawie bazy danych World Bank

\section{4. „Najstarsze" kraje świata}

\subsection{Skala starości}

Przeprowadzona powyżej analiza danych statystycznych (m.in. odsetka osób powyżej 65. roku życia) wykazała, że najwyższy poziom starości demograficznej występuje w Japonii i krajach europejskich, dlatego podjęte rozważania w dalszej części opracowania będą dotyczyły tych krajów. We wspomnianych krajach odnotowano zwiększanie się populacji ludzi starszych, ich udział jest obecnie największy w Japonii i wybranych krajach europejskich. Z tego też względu można powiedzieć, że są to „najstarsze demograficznie” kraje świata. Jak wcześniej pisano, do grupy tej zgodnie z prognozami już wkrótce dołączą kraje leżące w innych częściach świata. 
W latach 1990-2014 największy przyrost ludzi starych odnotowała Japonia, był to wzrost o blisko 14 punktów procentowych (rys. 8). Kraje europejskie znalazły się w tym rankingu na kolejnych miejscach, choć wzrost odsetka ludzi starych był znacznie mniejszy. Wśród krajów europejskich najwyższe wartości przyrostu osób w wieku 65 lat i więcej odnotowały: Malta (o 8,7 p.p.), Bośnia i Hercegowina (o 8,6 p.p.), Litwa (o 7,7 p.p.), Lotwa (o 7,4 p.p.), Włochy (o 7,2 p.p.) i Grecja (o 7,1 p.p.). W Polsce w tym okresie odsetek ludzi starych wzrósł o prawie 5 p.p.

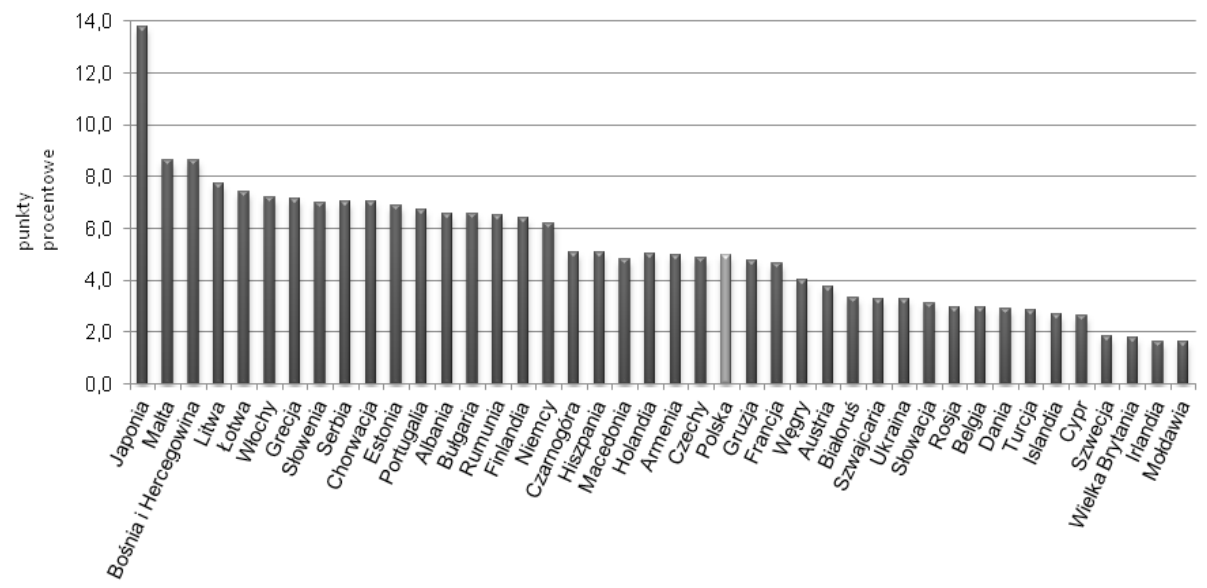

Rysunek 8. Wzrost udziału osób w wieku 65 lat i więcej pomiędzy 1990 i 2014 r.

Źródło: opracowanie własne na podstawie bazy danych Eurostat

Warto zwrócić uwagę, że w Japonii problem starzejącego się społeczeństwa jest znaczącym, lecz i stosunkowo nowym wyzwaniem. W roku $1960 \mathrm{w}$ Japonii osoby starsze stanowiły $5,7 \%$ populacji, podczas gdy ich udział w populacji Francji i Szwecji wynosił ponad 11\%, a w Stanach Zjednoczonych ponad 9\%. Podobna sytuacja utrzymywała się jeszcze w latach osiemdziesiątych XX w., kiedy to osób w wieku 65 lat i więcej było w Japonii nieco powyżej 9\% ogółu ludności, w Szwecji ponad 17\%, we Francji ponad 13\%, a w Stanach Zjednoczonych ponad $11 \%$. Gwałtowny wzrost liczby osób powyżej 65. roku życia nastąpił w Japonii dopiero od lat dziewięćdziesiątych ubiegłego wieku (Pieliński, 2012). W $1990 \mathrm{r}$. osoby starsze w tym kraju stanowiły 11,9\% populacji, a w 2014 już $25,8 \%$. Wynika $\mathrm{z}$ tego, że Japonia ze społeczeństwa, w którym proces starzenia przebiegał wolniej niż w innych krajach, wkroczyła na drogę społeczeństwa starzejącego się w szybkim tempie. Jednocześnie stała się, w dość krótkim czasie, krajem o najwyższym odsetku osób powyżej 65. roku życia.

Starzenie się populacji Japonii jest wynikiem dwóch trendów demograficznych: wzrostu długowieczności i spadku dzietności. Jeszcze w latach czterdzie- 
stych ubiegłego wieku TFR był wysoki i w 1940 r. wynosił 4,12, w 1949 4,32², a od połowy XX w. dzietność zaczęła systematycznie spadać (rys. 9). Zdaniem badaczy japońskiej demografii R. Retherforda i N. Ogawy (2005), w powojennym cyklu zmian dzietności można wydzielić trzy etapy:

- lata 1947-1957, kiedy współczynnik dzietności w Japonii zmniejszył się o ponad połowę (z 4,54 do 2,04),

- lata 1957-1973, kiedy współczynnik dzietności się ustabilizował (na poziomie 2,04-2,14)

- od 1973 do dnia dzisiejszego, kiedy współczynnik dzietności ponownie zaczął spadać, inicjując niekończący się niż demograficzny (do 1,42 w 2014 r.).

Spadek liczby narodzonych dzieci w okresie powojennym spowodowany był głównie trudną sytuacją kraju, który dopiero co otrząsał się z dramatycznych wydarzeń II wojny światowej. Nie bez znaczenia dla spadku dzietności była również legalizacja aborcji w 1948 r. Drugi etap obejmuje okres japońskiego wzrostu gospodarczego i jednocześnie stanowi lata stabilizacji liczby urodzeń. Stabilizacja ta oznaczała, że współczynnik dzietności przekraczał w tym czasie tzw. próg zastępowalności. W tym okresie wynosił niemalże nieprzerwanie około 2,1. Jednakże kryzys naftowy lat siedemdziesiątych XX w., a w konsekwencji recesja gospodarcza Japonii i galopująca inflacja ponownie wpłynęły na liczbę narodzin w tym okresie. Począwszy od 1973 r., odsetek narodzin wykazuje tendencję spadkową. Jeszcze w 1973 r. współczynnik dzietności w Japonii wynosił 2,14, a w 2005 r. spadł do 1,26, co stanowiło najniższy wynik w historii tego kraju. Statystyki wykazują, iż od 2005 r. współczynnik nie przejawia znaczących tendencji spadkowych, ale mimo jednoczesnego wzrostu liczby zgonów wśród stale rosnącej grupy osób starszych, próg zastępowalności wydaje się być w tym momencie nieosiągalny (Warchoł, 2015).

Wymienione wyżej przyczyny zewnętrzne warunkujące niski współczynnik urodzeń nie są jedynymi determinantami mającymi wpływ na przemiany zachowań prokreacyjnych społeczeństwa japońskiego. Kraj ten, podobnie jak inne wysoko rozwinięte państwa, objęły przemiany związane z drugim przejściem demograficznym. Koncepcja ta do czynników wyjaśniających przemiany zachowań demograficznych włącza szeroko rozumianą modernizację społeczeństwa, w tym ewolucję przekonań i stylu życia (np. decyzje o późniejszym posiadaniu dzieci, chęć kontynuowania kariery, model rodziny $2+1)$.

${ }^{2}$ W latach 1947-1949 na świat przyszło ponad 8 milionów dzieci. Osoby urodzone w tych latach weszły w wiek emerytalny około 2007 roku. W tym czasie zaczęto mówić o ,problemie 2007 roku", czyli o konsekwencjach przejścia na emeryturę osób urodzonych podczas wyżu demograficznego dla sytuacji ekonomicznej kraju - Baby boom sets Japan '2007 problem', http://news. bbc.co.uk/2/hi/asia-pacific/5263514.stm [dostęp: 4.08.2016]. 


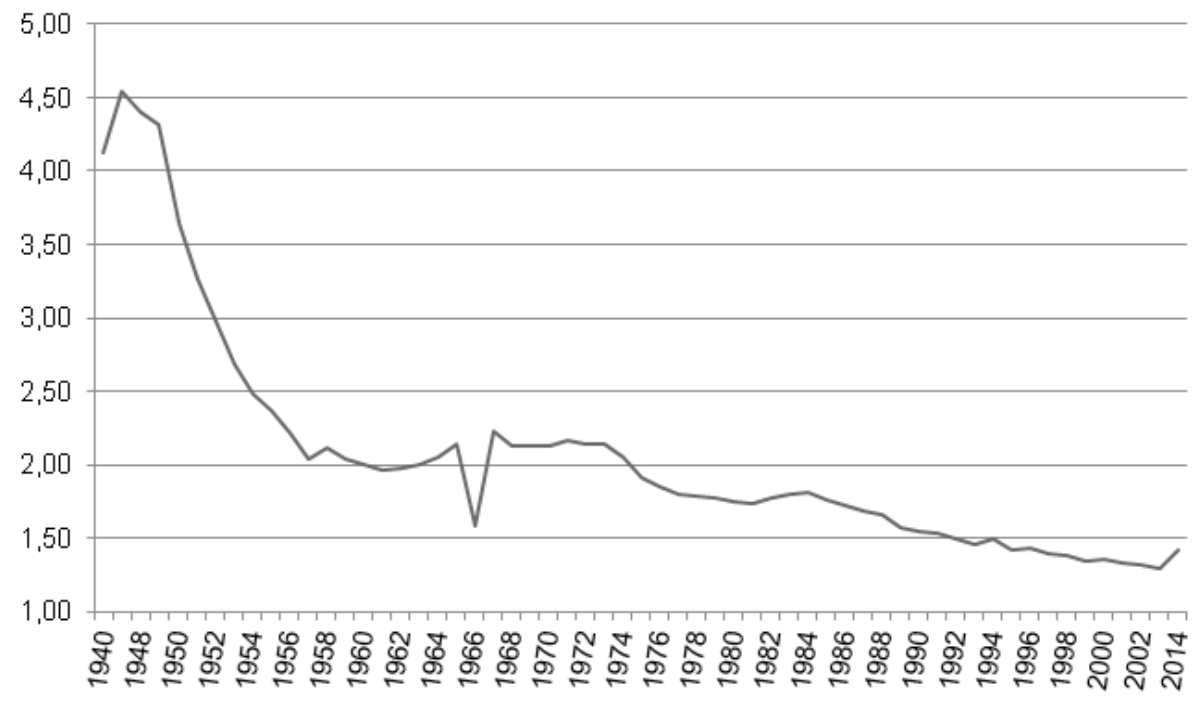

Rysunek 9. Wskaźnik dzietności w Japonii w latach 1940-2014

Źródło: opracowanie własne na podstawie bazy danych Statistics Japan

Przyczyną powiększania się grupy osób starszych jest ponadto wydłużenie się średniej długości życia. Podniesienie standardów życia, postęp medycyny i rozwój opieki społecznej sprawiły, że długość życia stale wzrasta. Jak pokazują raporty Światowej Organizacji Zdrowia, Japonia zajmuje pierwsze miejsce pod względem średniej długości życia, która wynosi 84 lata, uwzględniając obie płcie (WHO, 2016). Dla porównania, w Polsce średnia długość życia wynosi 77, a w USA 79 lat. Starzenie się społeczeństwa w Japonii jest najbardziej widoczne na obszarach wiejskich, gdzie dodatkowo odnotowuje się duży odpływ ludności w wieku produkcyjnym do miast. Spadek liczby ludności na terenach wiejskich oznacza pojawiające się społeczne ograniczenia mieszkańców tych obszarów, a z drugiej strony migracja do terenów zurbanizowanych oznacza ich przeludnienie (Lützeler, 2008). Ze względu na to, że migracja dotyczy głównie ludzi młodych, odsetek populacji w wieku rozrodczym na obszarach wiejskich gwałtownie spada. Obszary te od drugiej połowy lat dziewięćdziesiątych XX w. zmagają się z depopulacją (Warchoł, 2015).

\section{Demograficzne konsekwencje starzenia się ludności}

Ludność starsza nie stanowi jednorodnej zbiorowości. Subpopulacja osób w wieku 65 lat i więcej, ze względu na znaczną różnorodność swojej struktury wewnętrznej, podlega dalszym podziałom, w wyniku których wyodrębniane bywają grupy np. „młodszych starych”, „starszych starych” i stulatków. Jest to wynik wydłużania się 
życia i powiększania się odsetka osób, także w tych grupach wiekowych. Określa się to jako tzw. podwójne i potrójne starzenie się ludności (Kowaleski, 2008).

Najliczniejszą grupę wśród osób starych w omawianych krajach stanowią „młodzi starzy”, tj. osoby w wieku 65-74 lata (rys. 10). Grupa ta stanowi powyżej 60\% wszystkich osób 65+ w takich krajach, jak: Macedonia, Liechtenstein, Turcja, Albania i Czechy, a w Polsce jest to blisko 54\%. Osoby w wieku 75-84 lata obejmują mniej liczną subpopulację ludzi starych, od 27,8\% w Lichtensteinie do 39,3\% w Azerbejdżanie (rys. 11). „Najstarsi starzy” są najmniej liczną grupą wśród seniorów - największy ich udział mają Francja 15,9\% oraz Japonia 14,5\%. Niewielki odsetek ludzi powyżej 85 lat występuje w Macedonii. Jest to tylko 5,4\% ogółu ludzi starszych w tym kraju (rys. 12). W ramach procesu starzenia mówimy także o eksplozji stulatków. Według Urzędu Statystycznego Japonii na 1 kwietnia 2016 r. w Japonii żyło 70 tys. osób mających 100 lat i więcej, w tym 10 tys. mężczyzn i 60 tys. kobiet (Statistics Japan, 2016). W Polsce w 2014 r. takich osób było 4828 (z czego mężczyźni stanowili 20\%) (GUS, 2015).

Starzenie się ludności niesie z sobą różne konsekwencje. Dotyczą one sfery gospodarki, opieki zdrowotnej, relacji międzypokoleniowych w społeczeństwie i w rodzinie (Szukalski, 2011). Biorąc pod uwagę konsekwencje ekonomiczne, podstawowe znaczenie ma zwiększające się obciążenie ludności w wieku produkcyjnym ludnością w wieku nieprodukcyjnym. Miarą bazującą na relacjach między głównymi (funkcjonalnymi) grupami wieku jest ogólny (całkowity) współczynnik obciążenia demograficznego (total dependency ratio - TDR). Miernik ten jest sumą dwóch współczynników: współczynnika obciążenia osobami w wieku przedprodukcyjnym (youth dependency ratio) i współczynnika obciążenia osobami w wieku poprodukcyjnym (old-age dependency ratio).

Obciążenie ludności w wieku produkcyjnym dziećmi i osobami starymi w 2014 r., spośród omawianych krajów, było największe w Japonii, na 100 dorosłych mieszkańców tego kraju przypadały 63 osoby w wieku nieprodukcyjnym (rys. 13A). Wysokie wartości tego współczynnika odnotowały Włochy, Francja, Szwecja, Finlandia, zaś najmniejszy TDR (poniżej 40) odnotowały Mołdawia i Azerbejdżan.

Ludność w wieku produkcyjnym jest obciążona w rożnym stopniu osobami w wieku nieprodukcyjnym. W krajach takich, jak: Japonia, Niemcy, Włochy i Grecja, gdzie starzenie jest zaawansowane, osoby w wieku produkcyjnym są głównie obciążone ludźmi w wieku poprodukcyjnym (rys. 13B). Udział tego obciążenia stanowił ponad 2/3 (Japonia) lub blisko 2/3 (Niemcy, Włochy) ogólnej wartości współczynnika. W Japonii różnica między old-age dependency ratio a youth dependency ratio wyniosła ponad 20 punktów i była największą odnotowaną wśród krajów, dla których prowadzono analizę. W 18 krajach w obciążeniu ludności w wieku produkcyjnym większy udział mają osoby młode, w wieku przedprodukcyjnym (rys. 13C). Do krajów o największym youth dependency ratio należały Turcja (36) i Irlandia (34). 

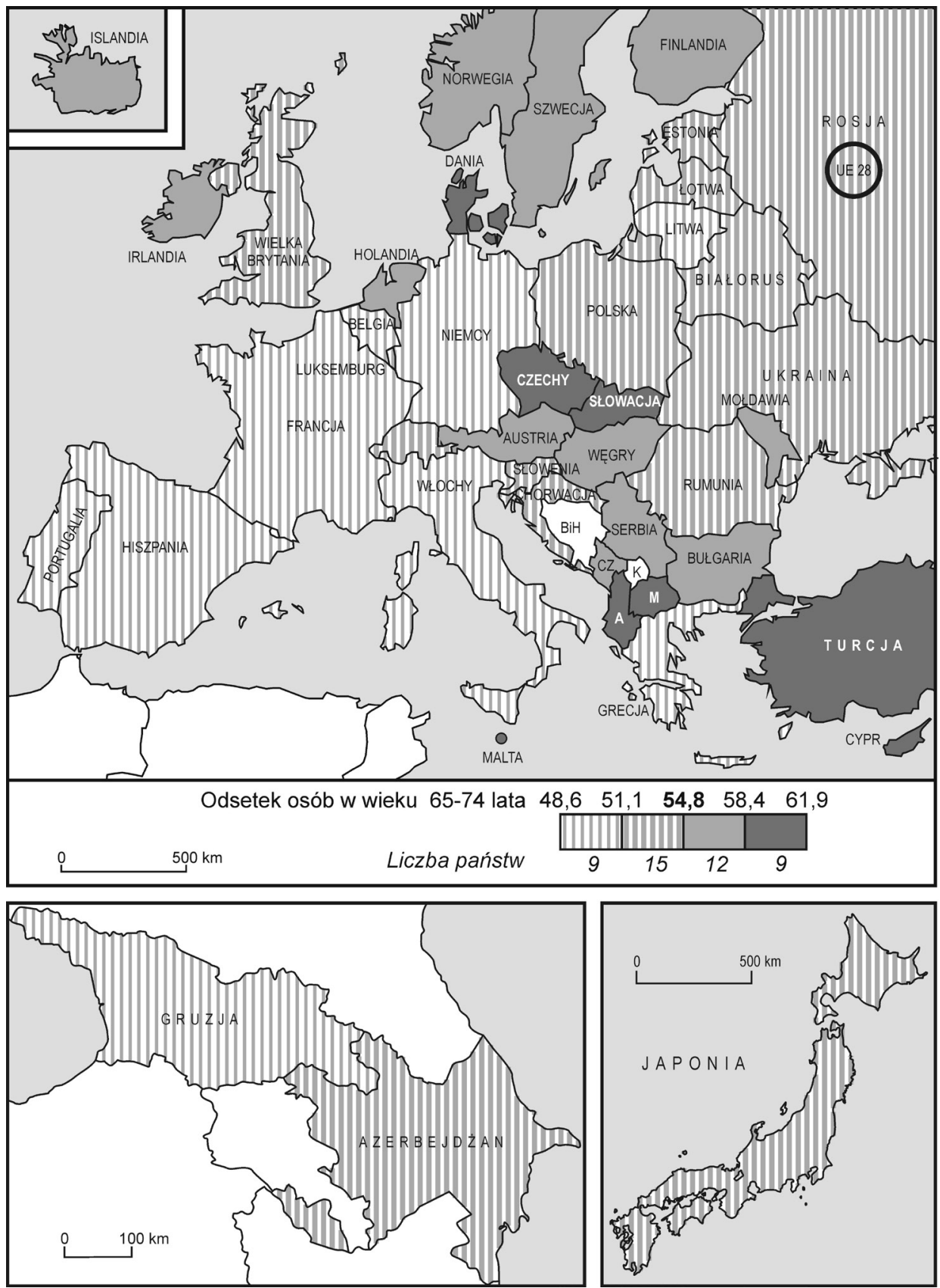

Rysunek 10. Odsetek osób w wieku 65-74 lata w krajach europejskich i Japonii w 2014 r. Źródło: opracowanie własne na podstawie bazy danych Eurostat 

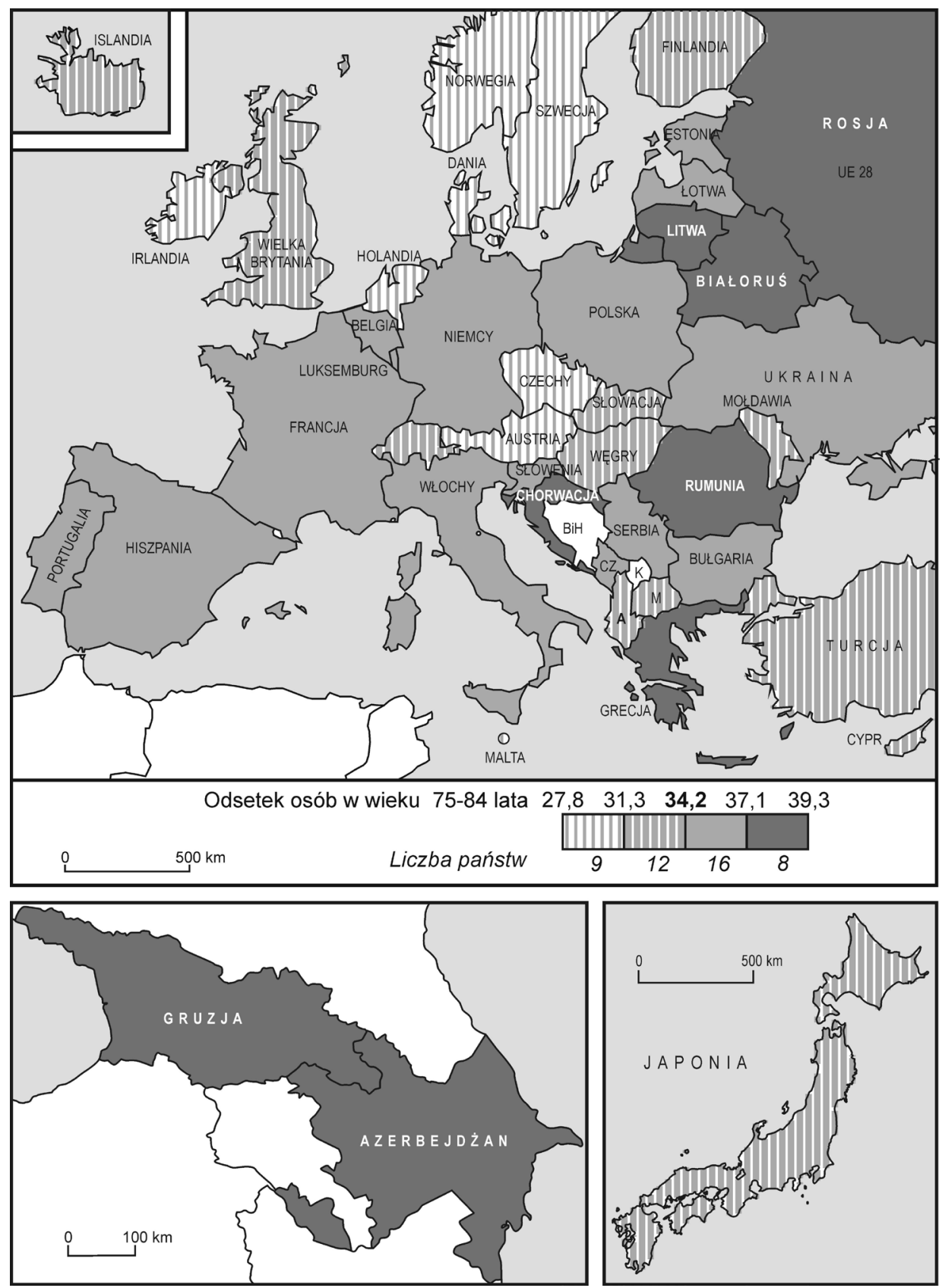

Rysunek 11. Odsetek osób w wieku 75-84 lata w krajach europejskich i Japonii w 2014 r. Źródło: opracowanie własne na podstawie bazy danych Eurostat 

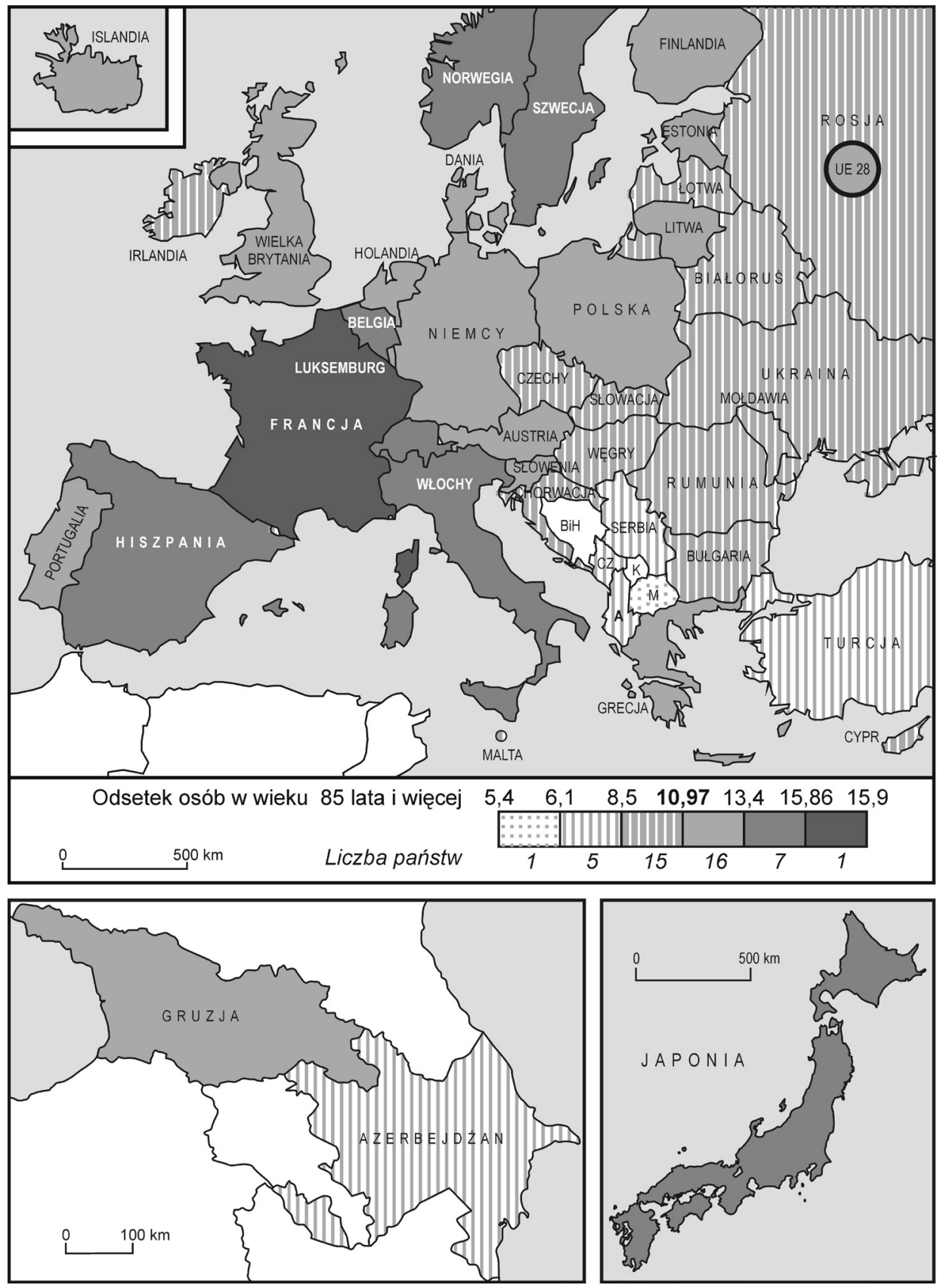

Rysunek 12. Odsetek osób w wieku 85 lat i więcej w krajach europejskich i Japonii w 2014 r. Źródło: opracowanie własne na podstawie bazy danych Eurostat 

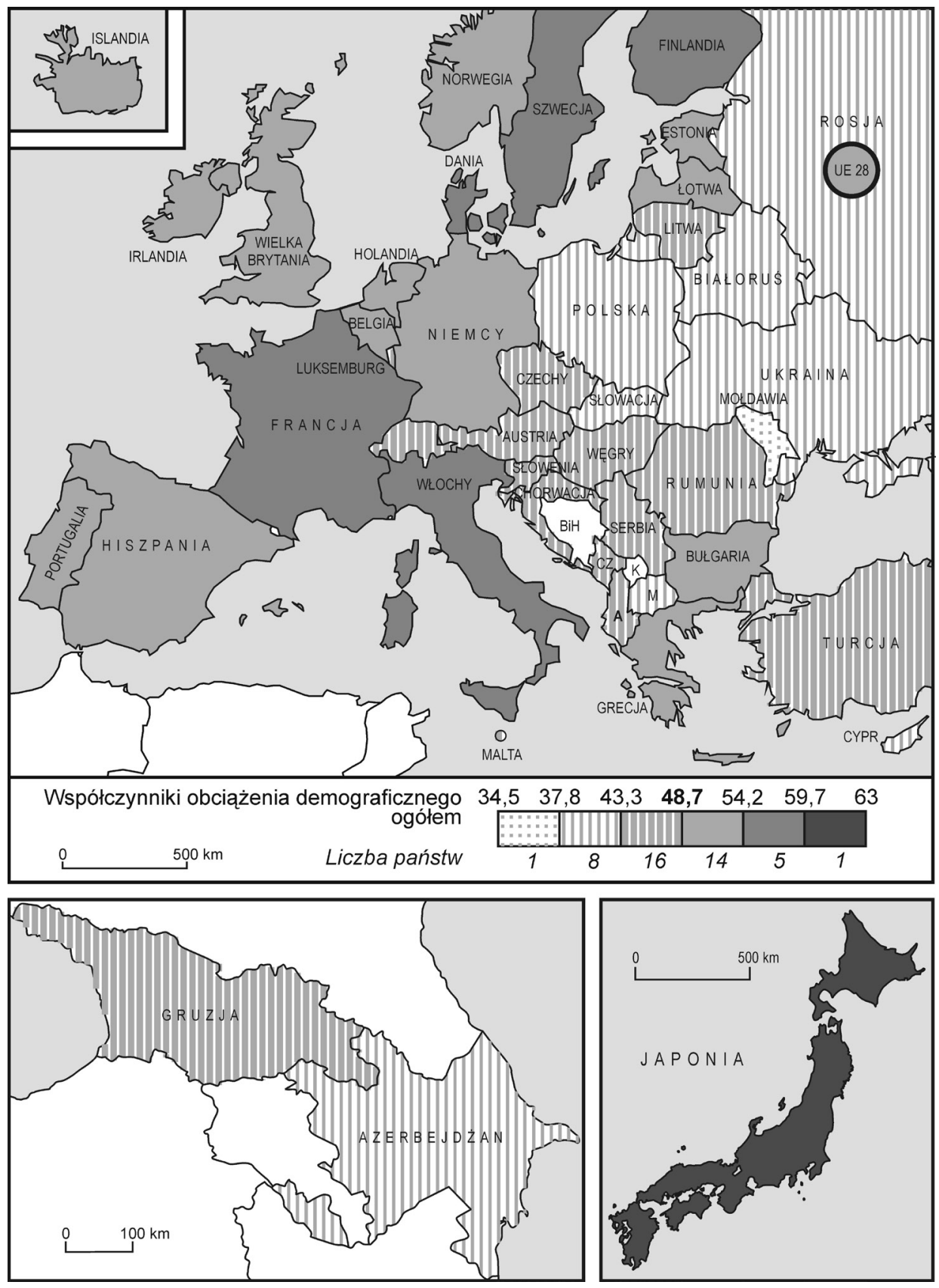

Rysunek 13A. Współczynnik obciążenia demograficznego ogółem w krajach europejskich i Japonii w 2014 r.

Źródło: opracowanie własne na podstawie bazy danych Eurostat 

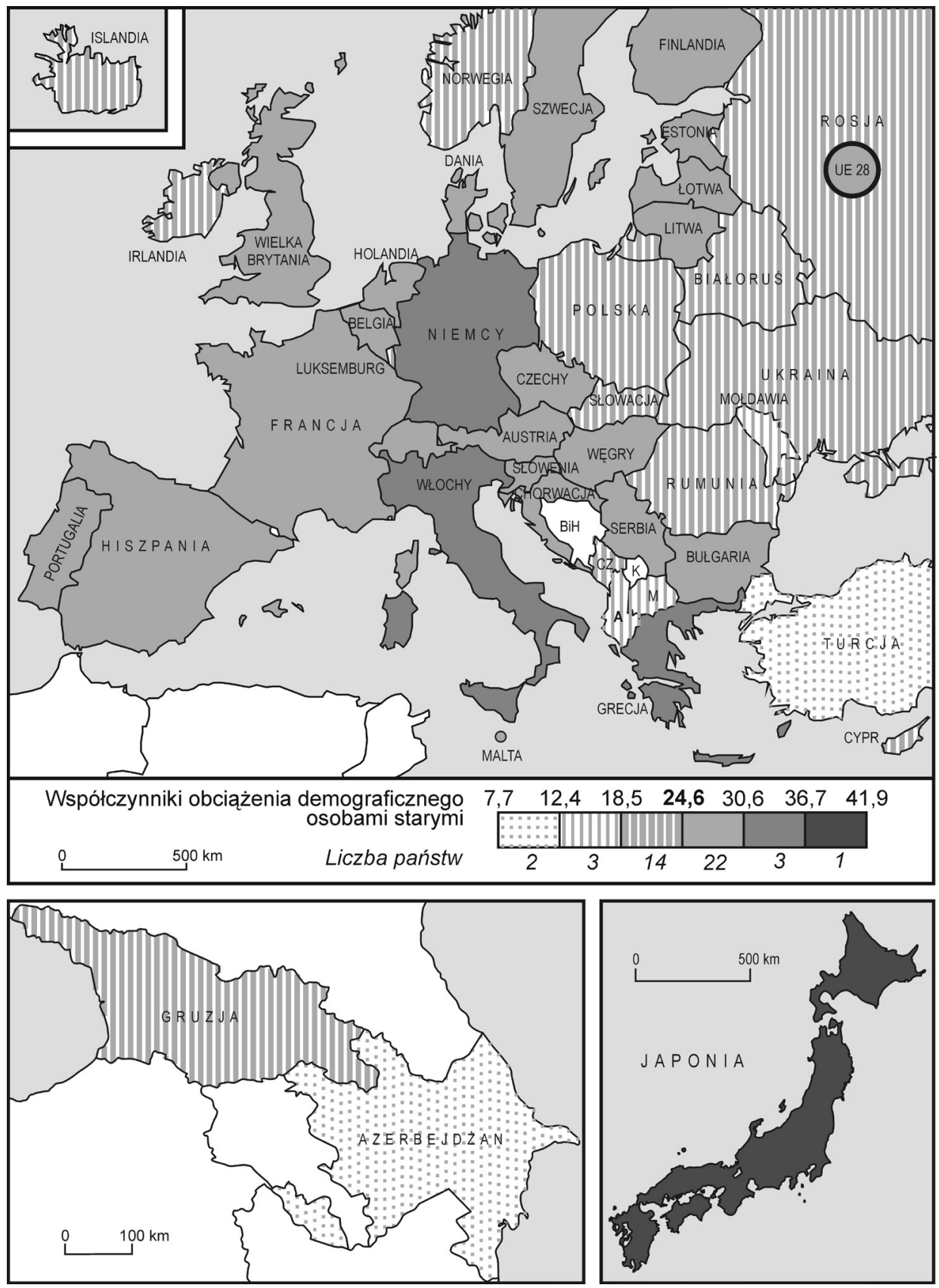

Rysunek 13B. Współczynnik obciążenia demograficznego osobami w wieku poprodukcyjnym w krajach europejskich i Japonii w 2014 r.

Źródło: opracowanie własne na podstawie bazy danych Eurostat 

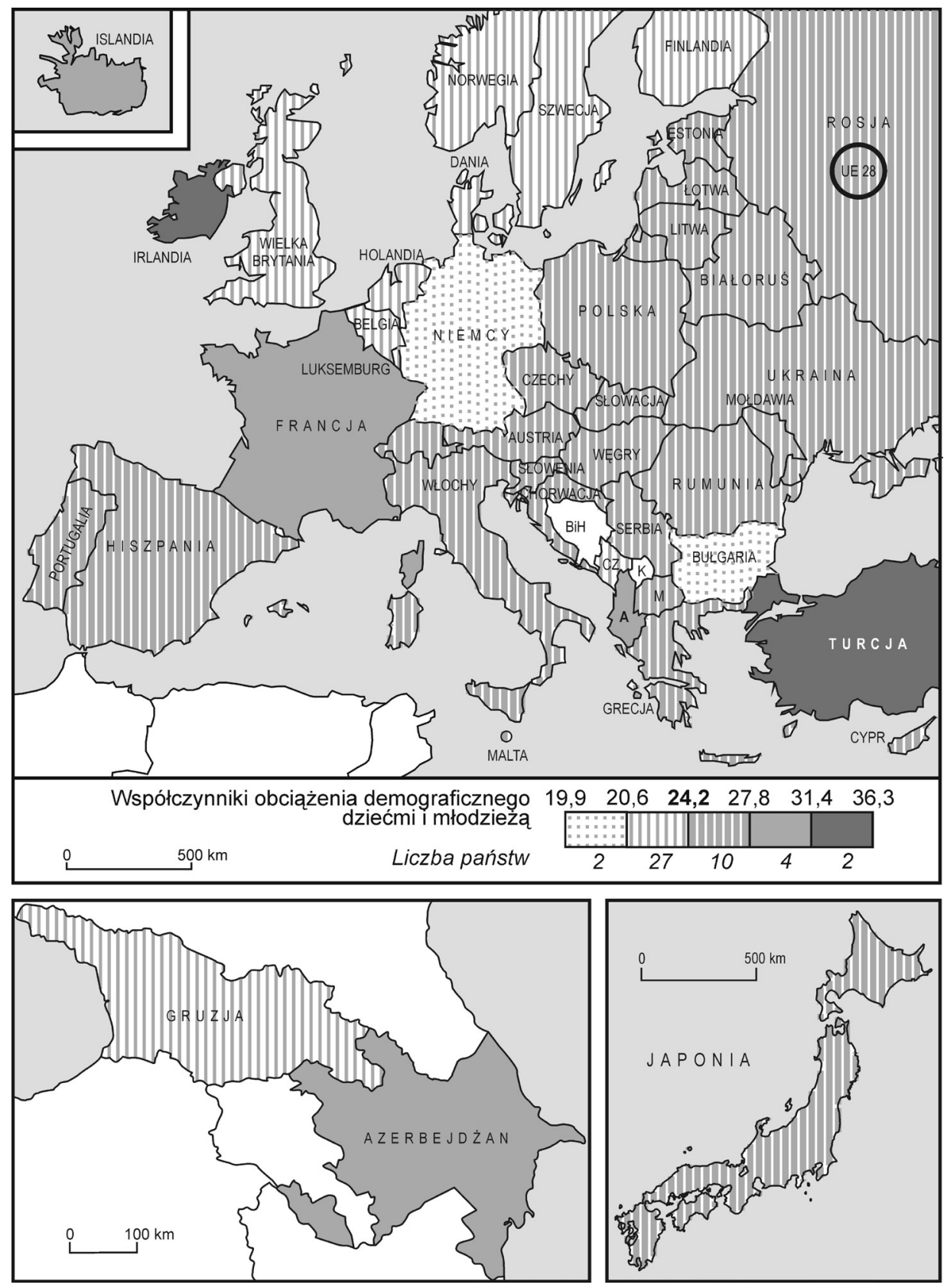

Rysunek 13C. Współczynnik obciążenia demograficznego: osobami w wieku przedprodukcyjnym w krajach europejskich i Japonii w 2014 r.

Źródło: opracowanie własne na podstawie bazy danych Eurostat 


\section{Podsumowanie}

W ostatnich latach można zaobserwować niepokojące, nie tylko demografów, trendy w populacji światowej, w tym postępujący proces starzenia się ludności. Świat się starzeje, choć tempo i rozmiary tego procesu są bardzo różne w zależności od kontynentu i regionu. Przeprowadzona analiza dostępnych danych statystycznych potwierdziła, że najwyższy poziom starości demograficznej występuje już od pół wieku na kontynencie europejskim. Należy jednak stwierdzić, że dynamika starzenia się ludności w Europie począwszy od lat dziewięćdziesiątych jest niższa niż w Ameryce Środkowej i Południowej czy w Azji, co oznacza rozprzestrzenianie się tego zjawiska na inne kontynenty.

Starzenie się ludności rozszerza się na coraz większą liczbę krajów i postępuje w wyniku spadku dzietności i wzrostu długowieczności. W rozpatrywanym okresie 1990-2014 tylko w nielicznych krajach zaobserwowano odmłodzenie, w pozostałych postępowało starzenie się ludności o różnym natężeniu i dynamice. Obecnie najstarszymi demograficznie krajami (uwzględniając odsetek ludzi starych) są Japonia i kraje europejskie (Niemcy, Włochy, Grecja). Prognozy demograficzne zakładają, że do krajów tych dołączą takie, które do tej pory nie były zaliczane do grupy państw ze starzejącym się społeczeństwem (np. Singapur, Tajlandia, Korea Południowa, Hong Kong, Kuba i Brunei).

Jedną z poważniejszych konsekwencji starzenia się ludności jest nie tylko sam proces szybkiego starzenia się, ale także wzrost wskaźnika zależności osób starych od ludzi aktywnych zawodowo. Szybkie starzenie się ludności w krajach rozwiniętych stworzy wiele poważnych problemów gospodarczych i społecznych, a na pracowników i pracodawców nałoży nowe, trudne do udźwignięcia ciężary. Przede wszystkim zwiększą się koszty wypłaty rent i emerytur, które obciążają budżet państwa. Można więc z dużym prawdopodobieństwem przewidzieć nie tylko ogromny wzrost wydatków na emerytury, lecz także na ochronę zdrowia i długotrwałą opiekę nad ludźmi starymi. Jeszcze trudniejsza sytuacja może wystąpić w krajach rozwijających się, w których brak jest obowiązującego w skali kraju programu emerytalnego (np. w Chinach). Może tam dojść do prawdziwej katastrofy, ponieważ rodziny nie będą w stanie utrzymać ludzi starych. Stąd problem starzenia się w krajach rozwijających się będzie miał o wiele poważniejsze następstwa, aniżeli proces starzenia się ludności w bogatych krajach Europy Zachodniej czy Ameryki.

\section{Bibliografia}

Bloom D.E., Canning D., Sevilla J. (2001), Economic Growth and the Demographic Transition, Cambridge, http://www.nber.org/papers/w8685.pdf [dostęp: 12.07.2015].

Długosz Z. (1998), Próba określenia zmian starości demograficznej Polski w ujęciu przestrzennym, „Wiadomości Statystyczne”, nr 3, s. 15-25. 
Gabryszak R. (2005), Tendencje demograficzne w starzejacym się świecie i ich konsekwencje, „Polityka Społeczna", nr 11-12, s. 14-18.

Giddens A. (2005), Socjologia, Wydawnictwo Naukowe PWN, Warszawa.

Główny Urząd Statystyczny (GUS) (2015), Rocznik Demograficzny 2015, Warszawa.

Golinowska S., Mazurkiewicz P. (1999), Ku godnej, aktywnej starości: Raport o Rozwoju Społecznym - Polska 1999, NHDR, Warszawa.

Grzędzińska E. (2005), Procesy demograficzne a rozwój gospodarczy. Wpływ starzenia się społeczeństwa na gospodarkę Polski, [w:] Materiały z XI Konferencji Naukowej Młodych Ekonomistów pt. Rozwój i Polityka gospodarcza Polski w Unii Europejskiej, 13-15 czerwca 2005 r., Sopot.

http://www.e-stat.go.jp/SG1/estat/ListE.do?lid=000001151137 [dostęp: 8.08.2016].

Jurek Ł. (2008), Demograficzne uwarunkowania zmian społecznych i ekonomicznych w regionie Azji i Pacyfiku, „Prace Naukowe Uniwersytetu Ekonomicznego we Wrocławiu”, nr 28, s. $98-109$.

Kowaleski J.T. (2008), Struktura demograficzna starszego odłamu ludności (rozważania metodologiczne i elementy obrazu sytuacji w województwach i powiatach na przełomie stuleci), [w:] J.T. Kowaleski, P. Szukalski (red.), Starzenie się ludności Polski. Między demografia a gerontologia społeczna, Wydawnictwo Uniwersytetu Łódzkiego, Łódź.

Kurek S. (2008), Typologia starzenia się ludności Polski w ujęciu przestrzennym, Wydawnictwo Naukowe AP, Kraków.

Kurkiewicz J. (1992), Podstawowe metody analizy demograficznej, PWN, Warszawa.

Lützeler R. (2008), Regional demographics, [w:] F. Coulmas, H. Conrad, A. Schad-Seifert, G. Vogt (eds.), The demographic challenge: A handbook about Japan, Boston, doi: 10.1163/ ej.9789004154773.i-1199.33.

Mikołajczyk B. (2012), Międzynarodowa ochrona praw osób starszych, Monografie Lex, Wolters Kluwer, Warszawa.

Ministerstwo Rodziny, Pracy i Polityki Społecznej (2002), Sprawozdanie z drugiego światowego zgromadzenia na temat starzenia się społeczeństw, Madryt, http://www.mpips.gov.pl/spoleczne-prawa-czlowieka/organizacja-narodów-zjednoczonych/madryckiplandziaaniawkwestiistarzeniasispoeczestw/, [dostęp: 12.07.2015].

Pieliński B. (2012), Polityka społeczna wobec starzejącego się społeczeństwa-rozwój systemu emerytalnego i systemu Ubezpieczenia Opieki Dtugoterminowej w Japonii, „Problemy Polityki Społecznej”, nr 18, s. 129-142.

Retherford R.D., Ogawa N. (2005), Japan's Baby Bust: Causes, Implications, and Policy Responses, „East-West Center Working Papers”, nr 118, s. 4-47.

Rosset E. (1982), Fenomeny demograficzne XX wieku, [w:] N. Wolański (red.), Ekologia populacji ludzkich, Zakład Narodowy im. Ossolińskich, PAN, Instytut Ekologii, Wrocław.

Statistics Japan, 2016, http://www.e-stat.go.jp/SG1/estat/ListE.do?lid=000001151137 [dostęp: 13.03.2015].

Stuart-Hamilton I . (2006), Psychologia starzenia się, Zysk i S-ka, Poznań.

Szukalski P. (2011), Starzenie się ludności-wyzwanie XXI wieku, [w:] P. Szukalski, Z. Szweda-Lewandowska, Elementy gerontologii spolecznej. Skrypt dla studentów Podyplomowego Studium Gerontologii Społecznej Uniwersytetu Łódzkiego, Wydawnictwo Biblioteka, Łódź.

United Nations Statistics Division (UNSD) (2014), Demographic Yearbook, http://unstats.un.org/ unsd/demographic/products/dyb/1990_round.htm [dostęp: 13.03.2015].

Warchoł P. (2015), Zmiany demograficzne jakko zagrożenie dla bezpieczeństwa. Analiza na przyktadzie Japonii, „Przegląd Strategiczny”, nr 8, s. 345-360, doi: 10.14746/ps.2015.1.23.

World Health Organization (WHO) (2016), World Health Statistics 2016: Monitoring health for the SDGs, http://www.who.int/gho/publications/world_health_statistics/2016/en/[dostęp: 4.08.2016]. 


\title{
The Worldwide Spatial Diversity in Population Ageing
}

\begin{abstract}
The ageing of populations is a currently global process which occurs in almost all regions of the world, although it is uneven in different countries. Doubtlessly, the changes in demographic behaviours observed at present contribute to the growing thereof, yet the process itself started much earlier. The work analyses statistical data and confirms that the most intense demographic ageing has been occurring for half a century in Europe. However, it needs to be mentioned that the dynamics of population ageing in Europe ever since the 1990s has been lower than in Central and South America or Asia which signifies the spreading of this phenomenon onto other continents. The main purpose of this work was to present the spatial diversity of population ageing in the world, sorted by continents and countries.
\end{abstract}

Keywords: population ageing, elderly people, spatial diversity, world, continents

JEL: J11, J13, J14, R23

\begin{tabular}{|l|l|}
\hline \multirow{2}{*}{ OPEN ACCESS } & $\begin{array}{l}\text { C by the author, licensee Łódź University - Łódź University Press, Łódź, Poland. } \\
\text { This article is an open access article distributed under the terms and conditions } \\
\text { of the Creative Commons Attribution license C(-BY } \\
\text { (http://creativecommons.org/licenses/by/3.0/) }\end{array}$ \\
\cline { 2 - 2 } & Received: 2016-10-01; verified: 2016-12-05. Accepted: 2017-10-02 \\
\hline
\end{tabular}

